УДК. 663.5

\title{
СНИЖЕНИЕ ЭНЕРГОЗАТРАТ ПРИ ПЕРЕРАБОТКЕ КРАХМАЛОСОДЕРЖАЩИХ СРЕД МЕТОДОМ ДИСКРЕТНО - ИМПУЛЬСНОГО ВВОДА ЭНЕРГИИ
}

\author{
Ободович А.Н., д.Т.н., Лымарь А.Н., Костик С.И., Сидоренко В.В.
}

Институт технической теплофизики НАН Украины, ул. Желябова, 2а, Киев, 03680, Украина

Розглянуто можливість застосування методу дискретно-імпульсного введення енергії при обробці крахмаловмісних середовищ. Представлені результати досліджень по гідролізу крахмалосодержащих середовищ. Доведено ефективність застосування методу на даному етапі виробництва спирту.
Рассмотрена возможность применения метода дискретно-импульсного ввода энергии при обработке крахмалосодержащих сред. Представлены результаты исследований по гидролизу крахмалосодержащих сред. Доказана эффективность применения метода.
The possibility in the processing of starch media has been considered. The results of studies on the hydrolysis of starch media are presented. The effectiveness of the method is proved.

Библ. 5, табл. 3, рис. 4.

Ключевые слова: дискретно-импульсный ввод энергии, гидролиз, сусло.

Вопросы энерго- и ресурсосбережения всегда были и, на сегодняшний день, остаются актуальными для всех отраслей промышленности. Наукой и практикой уже доказано, что метод ДИВЭ позволяет частично решать данные проблемы в фармацевтической, пищевой, химической и др. отраслях промышленности $[1,2,3]$. Изучение теплофизических процессов в сложных гетерогенных системах при воздействии механизмов ДИВЭ позволяет совершенствовать существующие и разрабатывать новые технологии и продукты.

Исходя из вышеизложенного, перед нами стояла задача исследования возможности применения метода ДИВЭ при переработке крахмалосодержащих зерновых культур.

Зерновые культуры являются одним из основных видов сырья для хлебопекарной, бродильной, крахмалопаточной и других отраслей промышленности. Зерновые культуры имеют различную форму зерна, но состоят из одинаковых анатомических частей: оболочки, зародыша и эндосперма.

Химический состав зерновых культур зависит от экологических (климатических и почвенных) и метеорологических условий. Он характеризуется такими основными группами веществ, как углеводы, жиры, белки и зольные элементы. Основную часть углеводов (около 98 \%) составляет крахмал. [4].
Переработка зерна практически во всех отраслях промышленности связана с диспергированием, смешиванием с водой или другой жидкой фазой, термообработкой и, при необходимости, гидролизом. Вышеуказанные технологические стадии переработки зерна осуществляется на отдельном оборудовании по установленным режимам.

Метод ДИВЭ, разработанный в ИТТФ НАН Украины, позволяет проводить данные технологические операции в одном РПА [5].

По традиционному способу переработки зерна в спиртовой промышленности его сначала измельчают, а затем смешивают с водой, проводят термообработку и гидролизуют. Переработка зерна с применением метода ДИВЭ осуществляется несколько иначе, чем по классической схеме

В приёмный бункер РПА задают воду, открывают кран и включают РПА. Вода рециркулирует по контуру через рабочие органы РПА. Затем открывают двухходовой кран и из бункера подают зерно в поток рециркулирующей воды. Количество зерна и воды составляет $1-2$ соответственно.

Водозерновая смесь проходит через проходит рабочие органы РПА в режиме рециркуляции, где происходит одновременное измельчение зерна, смешивание его с водой, растворение химических соединений и нагревание смеси. 
Нагревание смеси происходит за счёт энергии диссипации.

Обработку смеси ведут до температуры начала клейстеризации крахмала $45 \ldots 50{ }^{\circ} \mathrm{C}$, затем задают ферментный препарат - термостойкую бактериальную $\alpha$-амилазу. Ферментный препарат $\alpha$-амилаза разжижает крахмал и не даёт ему клейстеризоваться, а также частично его гидролизует. После добавления $\alpha$-амилазы обработку смеси продолжают до температуры $80 \ldots 85^{\circ} \mathrm{C}$. Такая температура необходима для разваривания крахмальных зёрен и перевода крахмала в растворённое состояние.

По достижению температуры $80 \ldots 85{ }^{\circ} \mathrm{C}$ в раствор добавляют ещё одну часть воды и охлаждают его до температуры $55 \ldots 60{ }^{\circ} \mathrm{C}$. После этого добавляют ферментный препарат глюкоамилазу и переводит гидролиз крахмала до получения сбраживаемых углеводов. Далее готовое сусло охлаждают и подают на сбраживание.

Отличительная особенность приготовления сусла спиртового производства с применением метода ДИВЭ состоит в том, что все технологические операции (диспергирование, перемешивание, растворение, нагревание, гидролиз) проходят в одном РПА.

Более подробно остановимся на наиболее важном и сложном в технологии спирта процессе гидролиза крахмала.

По классической технологии на процесс гидролиза крахмала и крахмалосодержащих соединений оказывают влияние следующие факторы: температура, $\mathrm{pH}$, природа и количество катализатора, продолжительность во времени [4]. По разработанному способу гидролиз будет проводиться с применением метода ДИВЭ и его механизмов.

При проведении исследований примем, что катализаторами будут ферментные препараты $\alpha$ - и глюкоамилазы. Оптимумом их действия является $\mathrm{pH} 5,0 \ldots 5,5$ и температура $70 \ldots 85{ }^{\circ} \mathrm{C}$ для $\alpha$-амилазы и $55 \ldots 58{ }^{\circ} \mathrm{C}$ для глюкоамилазы.

В процессе обработки гидролизуемой среды в РПА будем менять продолжительность процесса, частоту пульсаций, скорость сдвига потока, угловую скорость, зазор между статором и ротором. Частота пульсаций зависит от скорости вращения ротора и количества отверстий в рабочих органах. Скорость сдвига потока зависит от угловой скорости вращения ротора, радиуса ротора и зазора между статором и ротором.

В таблице 1 показана зависимость количества прогидролизованного крахмала в \% от продолжительности процесса и частоты пульсаций потока среды в РПА.

Данные таблицы 1 свидетельствуют о том, что с увеличением продолжительности процесса гидролиза увеличивается количество прогидролизированного крахмала. Без обработки в РПА (частота пульсаций 0) за 15 мин. гидролизуется $78 \%$ крахмала. С увеличением частоты пульсаций от 1 до 5 кГц количество прогидролизованного крахмала увеличится до $96 \%$.

Из таблицы видно, что при частоте пульсаций 3..5 кГц продолжительность осахаривания можно сократить до 10..12 мин. и достичь величины 96 \% прогидролизованного крахмала. Таким образом, проведение процесса гидролиза крахмалосодержащего сырья в РПА с частотой пульсаций потока $3 \ldots 5$ кГц позволяет повысить процент прогидролизованного крахмала от 78 до 96 и сократить продолжительность от 15 до $10 \ldots 12$ мин.

В дальнейших исследованиях было изучено воздействие угловой скорости вращения ротора на гидролиз крахмалосодержащих соединений.

Из графика можно сделать вывод о том, что с увеличением скорости вращения ротора продолжительность гидролиза уменьшается, а количество прогидролизованного крахмала увеличивается. Эффективность процесса гидролиза существенно улучшается при увеличении угловой скорости от $30 \cdot 2 \pi$ до $50 \cdot 2 \pi$ об/с . Увеличение угловой скорости до $70 \cdot 2 \pi$ об/с практически процесс гидролиза не улучшает. При повышении угловой скорости до $90 \cdot 2 \pi$ об/с наблюдается уменьшение количества прогидролизованного крахмала от 96 до 60 \%. По мнению авторов, вышеописанное можно объяснить тем, что при небольшом увеличении угловой скорости вращения ротора от $30 \cdot 2 \pi$ до $50 \cdot 2 \pi$ об/с повышается массообмен перерабатываемой среды, в результате чего улучшается взаимодействие между активным центром фермента и субстратом. То есть в единицу времени количество разорванных ацетальных связей $(\mathrm{C}-\mathrm{O}) \alpha 1-4$ и $(\mathrm{C}-\mathrm{C}) \alpha 1-6$ увеличивается. 
Табл. 1. Зависимость количества прогидролизованного крахмала (в \%) от продолжительности процесса и частоты пульсаций потока среды в РПА

\begin{tabular}{|c|c|c|c|c|c|c|}
\hline \multirow{2}{*}{ Частота пульсаций, кГц } & \multicolumn{7}{|c|}{ Время, мин } \\
\cline { 2 - 7 } & 3 & 5 & 7 & 10 & 12 & 15 \\
\hline 0 & 7 & 20 & 41 & 67 & 73 & 78 \\
1 & 17 & 39 & 75 & 76 & 80 & 89 \\
3 & 25 & 47 & 88 & 91 & 96 & 96 \\
5 & 28 & 49 & 89 & 92 & 96 & 96 \\
\hline
\end{tabular}

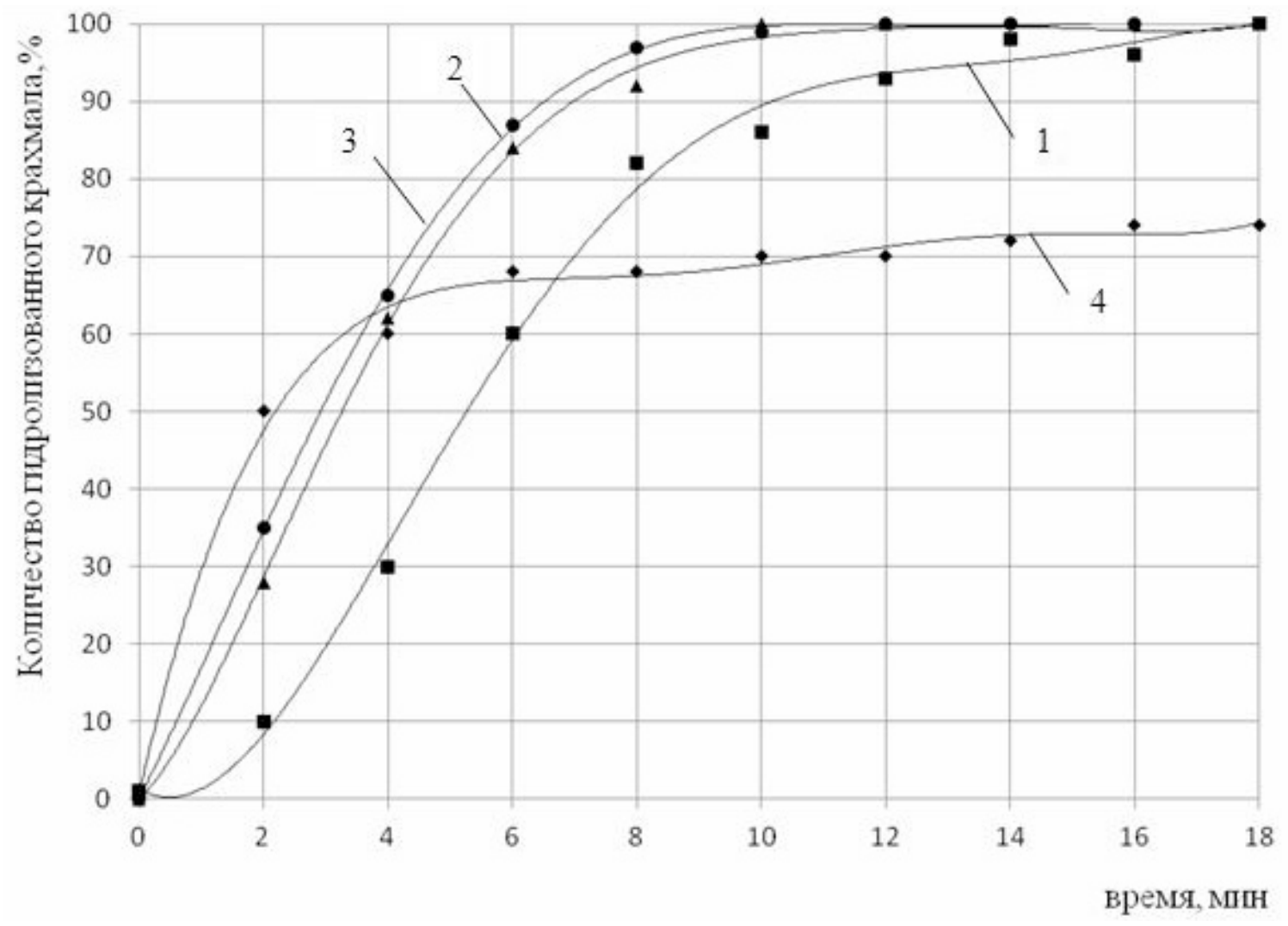

Рис. 1. Зависимость количества прогидролизованного крахмала (\%) от угловой скорости вращения ротора и продолюительности гидролиза: $1-30 \cdot 2 \pi$ об/c; $2-50 \cdot 2 \pi$ об/c; $3-70 \cdot 2 \pi$ об/c; $4-90 \cdot 2 \pi \sigma \sigma / c$.

Однако, увеличение угловой скорости до $90 \cdot 2 \pi$ об/с способствует ухудшению процесса гидролиза. По видимому, большие угловые скорости приводят к разрушению активного центра фермента и снижению его активности.

Проведенные исследования позволяют сделать вывод о том, что наиболее эффективно проходит процесс гидролиза крахмала при угловой скорости вращения ротора $50 \cdot 2 \pi$ об/с. Одним из факторов, влияющих на обработку гетеро- генных сред в РПА является величина зазора между статором и роторм.

При проведении данных исследований угловая скорость вращения ротора оставалась постоянной и составляла $50 \cdot 2 \pi$ об/с.

График зависимости количества прогидролизованного крахмала (\%) от продолжительности гидролиза и зазора между статором и ротором представлена на рис. 2.

Уменьшение зазора между статором и ро- 


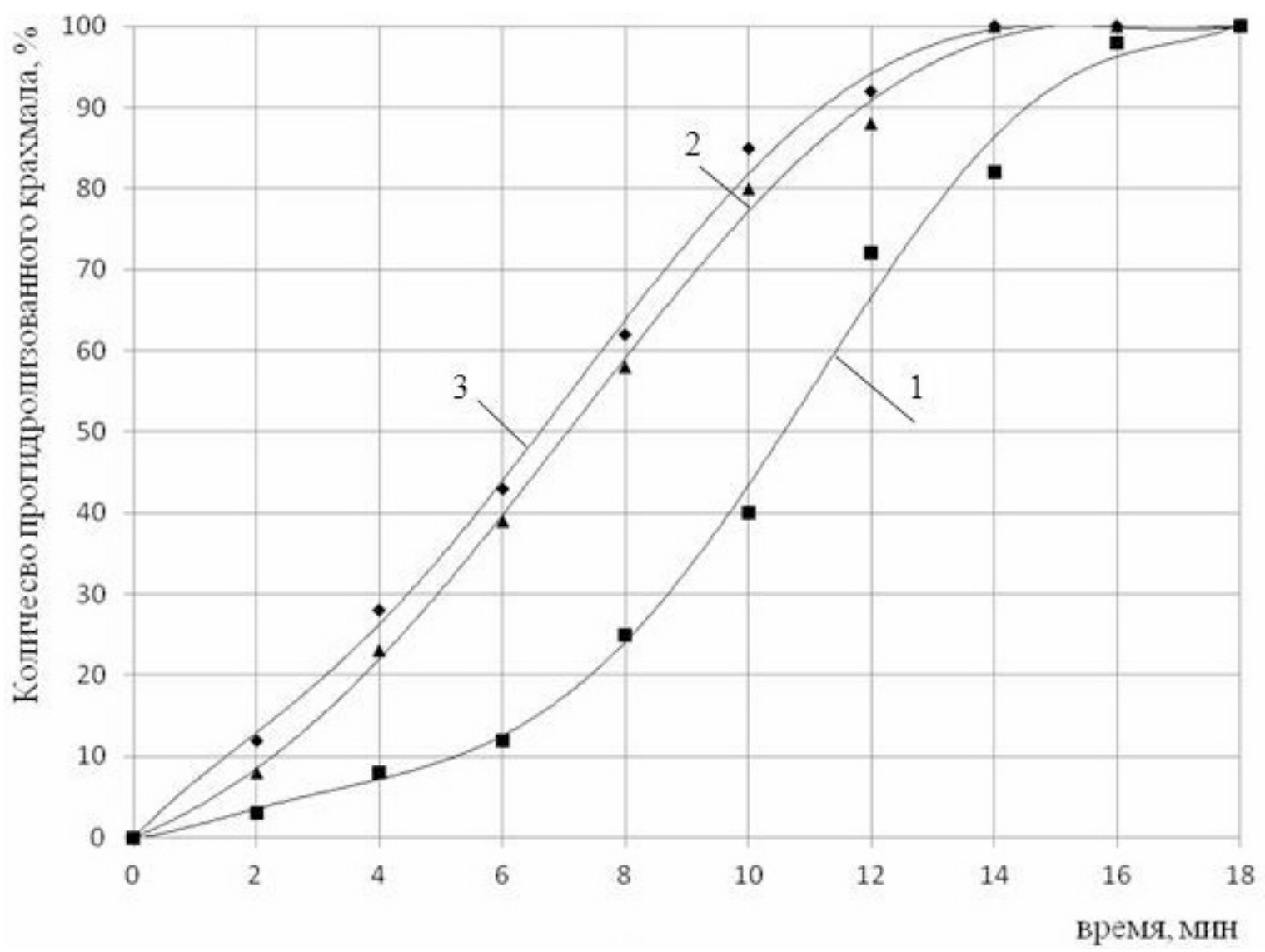

Рис. 2. Зависимость количества прогидролизованного крахмала (\%) от продолюсительности гидролиза и зазора между статором и ротором: 1 - 500 мкм; 2 - 300 мкм; 3 - 100 мкм.

тором от 500 до 300 мкм положительно влияет на процесс гидролиза крахмала. Позволяет гидролизовать его на 97...98 \% и снизить продолжительность процесса от 18 до $13 \ldots 14$ мин. Уменьшение зазора меньше 100 мкм нецелесообразно, т.к. большая вязкость среды будет затруднять её перемешивание и перекачивание.

Угловая скорость вращения ротора и зазор между статором и ротором объединяет новая введенная величина - скорость сдвига потока $\gamma\left(\mathrm{c}^{-1}\right)$.

Дальнейшими исследованиями было определено влияние скорости сдвига потока обрабатываемой среды в РПА на процесс гидролиза крахмала. Скорость сдвига потока меняли путём изменения угловой скорости вращения ротора, внутреннего радиуса ротора и величины зазора между статором и ротором. Она составляла $30,50,70 \cdot 10^{3} \mathrm{c}^{-1}$.

Зависимость количества прогидролизован- ного крахмала от продолжительности процесса и скорости сдвига потока представлена в таблице 2.

Данные таблицы свидетельствуют о том, что увеличение скорости сдвига потока от 0 до $50 \cdot 10^{3} \mathrm{c}^{-1}$ существенно увеличивает количество прогидролизованного крахмала от 75 до $96 \%$ и сокращает продолжительность процесса на $20 \%$. С увеличением скорости сдвига потока до $70 \cdot 10^{3} \mathrm{c}^{-1}$ количество прогидролизованного крахмала практически не увеличивается.

Анализируя экспериментальные данные, отражённые в таблицах и графиках приходим к выводу, что процесс гидролиза крахмалосодержащего сырья наиболее эффективно проводить при обработке среды в РПА при скорости сдвига потока $50 \cdot 10^{3} \mathrm{c}^{-1}$ и частоте пульсаций 3 кГц.

Ранее было указано, что с уменьшением среднего размера частиц зерна и повышением температуры начинается клейстеризация крах- 
Табл. 2. Зависимость количества прогидролизованного крахмала (в \%) от продолжительности процесса и скорости сдвига потока

\begin{tabular}{|c|c|c|c|c|c|c|}
\hline Скорость сдвига потока & \multicolumn{6}{|c|}{ Продолжительность гидролиза, мин } \\
\cline { 2 - 7 }$\gamma\left(\mathrm{c}^{-1}\right)$ & 3 & 5 & 7 & 10 & 12 & 15 \\
\hline 0 & 6 & 23 & 45 & 61 & 70 & 75 \\
$30 \cdot 10^{3}$ & 17 & 48 & 67 & 85 & 90 & 94 \\
$50 \cdot 10^{3}$ & 21 & 44 & 75 & 92 & 96 & 96 \\
$70 \cdot 10^{3}$ & 23 & 46 & 76 & 93 & 96 & 97 \\
\hline
\end{tabular}

мала. Это приводит к резкому увеличению вязкости среды, что влечёт за собой трудности в её переработке. Поэтому, с целью разжижения и гидролиза среды, в неё добавляют ферментные препараты $\alpha$ - амилазу и глюкоамилазу. Вследствие вязкость разжиженных и гидролизованных крахмальных растворов уменьшается до 0,2...0,3 Па·с. Это позволяет готовый продукт легко перемешивать и перекачивать.

Экспериментально установлено, что для приготовления 1 т. сусло с применением метода ДИВЭ необходимо затратить 4,7 кВт электроэнергии. Данный показатель по существующей технологии составляет 6,5 кВт·час.

Для спиртового завода производительностью 3000 дал спирта в сутки необходимо 300 т сусла.

Суточная потребность в электроэнергии для приготовления сусла по существующей технологии составляет $6,5 \cdot 300=1950$ кВт·ч, по получаемой $4,7 \cdot 300=1410$ кВТ·ч.

В среднем спиртовые заводы работают 300 суток в год.

$1950 \cdot 300=585000$ кВт·ч - существующая технология, $1410 \cdot 300=423000$ кВт·ч - предлагаемая технология.

Итого годовая экономия энергозатрат для одного спиртового завода составляет 162000 кВт·ч.

В Украине работает 40 спиртовых заводов. Годовой экономический эффект по Украине составляет $162000 \cdot 40=6480000$ кВт $\cdot$.

При проведении процесса гидролиза крахмалосодержащих соединений количество ферментного препарата задавали по принятым в спиртовой промышленности для осахаривания сусла нормам. На 1 тонну крахмала 1 кг $\alpha$-амилазы и 1 кг глюкоамилазы. Затраты осахаривающих материалов наиболее правильно рассчи- тывать по единицам их активности на единицу массы крахмала. Одним из показателей активности ферментов, отвечающих за гидролиз крахмала, является осахаривающая активность (ОА), которая характеризует способность всех амилотических ферментов катализировать гидролиз крахмала до редуцирующих веществ. Активность осахаривающих материалов характеризуют числом единиц осахаривающих ферментов, находящихся в 1 г ферментного препарата.

За единицу осахаривающей активности принимают такое количество ферментов, которые в строго определенных условиях (температура $30, \mathrm{pH}-4,7 \ldots 4,9$, период действия - 60 мин) катализирует гидролиз 1 г крахмала, который не превышает 30 \% введенного в ферментативную реакцию. Как правило, осахаривающая активность амилолитических ферментных препаратов составляет от 0,1 до 8,0 ед./100 $\left.\mathrm{cm}^{3}\right)$. При использовании ферментных препаратов для гидролиза крахмала определяют осахаривающую активность и, исходя из этого, рассчитывают их количество.

Ранее проведенные исследования показали, что применение метода ДИВЭ позволяет увеличить скорость реакции гидролиза крахмала почти в 2 раза. Продолжительность реакции уменьшается с 20 до 10 мин.

Используя РПА, мы улучшаем взаимодействие фермента и субстрата. Т.е. в принудительном порядке за счет скорости и частоты пульсаций потока заставляем одно и тоже количество фермента гидролизовать в единицу времени большее количество связей $(\mathrm{C}-\mathrm{O})$ и $(\mathrm{C}-\mathrm{C})$. Иными словами повышаем активность фермента. При этом возникает вопрос о том, можно ли с увеличением активности фермента уменьшить его количество при гидролизе еди- 
ницы крахмала.

Для этого были проведены исследования по уменьшению (от установленной нормы) количества ферментных препаратов на 5, 10, 15 и $20 \%$. Данные экспериментов представлены на рисунке 3.

Из графика видно, что при снижении содержания ферментного препарата от 100 до $80 \%$ продолжительность времени для проведения гидролиза увеличивается от 10 до 15 мин. Уменьшение количества ферментного препарата на $5 \ldots 15 \%$ возможно практически без изменения продолжительности процесса.

Таким образом, применение метода ДИВЭ эффективно при гидролизе крахмалосодержащего сырья. Данный метод позволяет сократить продолжительность процесса в 2 раза, увеличив при этом количество прогидролизованного крахмала от 76 до $97 \%$.

В процессе исследований установлено, проведение процесса гидролиза с применением метода ДИВЭ позволяет с одинаковым количеством ферментных препаратов проводить реакцию в 2 раза быстрее и с большим количеством прогидролизованного крахмала. Это наводит на мысль, что активность ферментов в результате воздействия механизмов ДИВЭ может изменяться.

Поэтому следующим этапом исследований было определение влияния механизмов ДИВЭ на осахаривающую активность амилолитических ферментных препаратов. Из механизмов

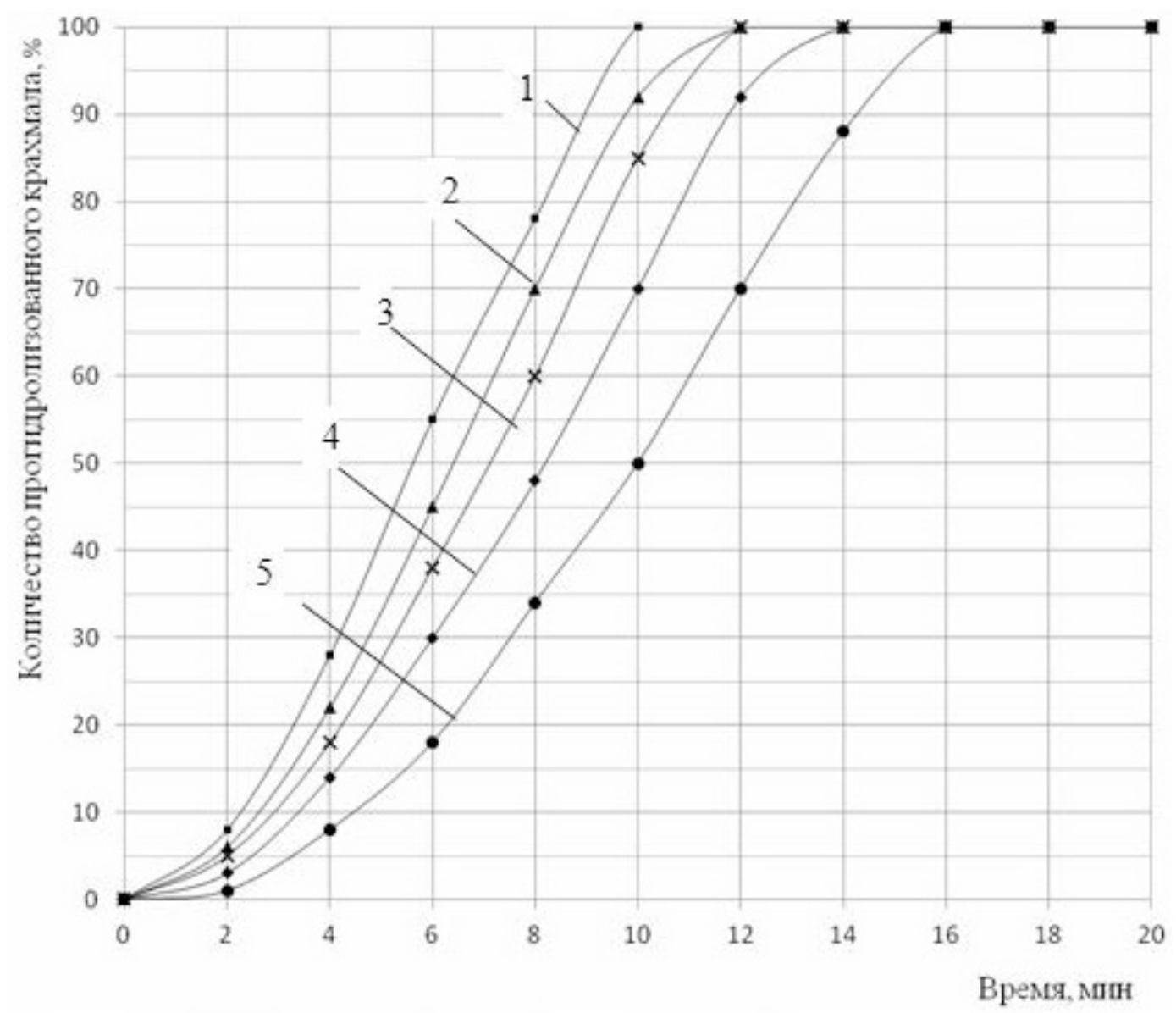

Рис. 3. График зависимости количества прогидролизованного крахмала от времени при затратах ферментных препаратов: 1 - $100 \%$; 2 - $95 \%$; 3 - $90 \%$; 4 - 85 \%; 5 - $80 \%$. При проведении исследований, гидролиз крахмалосодержащего сырья проводили методом ДИВЭ при частоте пульсаций 3 кГц, скорости сдвига потока $50 \cdot 10^{3} \mathrm{c}^{-1}$, амплитуде перепада давлений $\triangle P 520$ кПа. 
ДИВЭ были выбраны частота пульсаций и скорость сдвига потока среды в РПА.

График зависимости осахаривающей активности (ОА) ферментов от продолжительности процесса и частоты пульсаций среды в РПА представлен на рис. 4. При проведении исследований измеряли начальную осахаривающую активность ферментных препаратов. Она составляла 3,4 ед./100 $\mathrm{cm}^{3}$.

OA препаратов при проведении процесса гидролиза сначала увеличивается почти в 2 раза, а затем уменьшается. При проведении гидролиза с частотой пульсаций среды 3..5 кГц наибольшая ОА ферментов наблюдается на $10 \ldots$ 12 мин. обработки. Затем она падает. При проведении гидролиза с частотой пульсаций 1 кГц ОА увеличивается меньше и на 15 минуте обработки.
Тоже происходит ее уменьшение. По мнению авторов это объясняется тем, что до определенного момента (частота пульсаций и продолжительность) активный центр фермента чаще встречается с ацетальной связью в молекуле крахмала и разрывает ее. Повышенная частота пульсаций и продолжительность гидролиза повидимому ингибирует активный центр фермента.

Для доказательства правильности данного предположения было исследовано влияние скорости сдвига потока и продолжительности гидролиза на ОА ферментов (табл. 3).

Данные таблицы подтверждают выдвинутые ранее предположения о том, что воздействие механизмов ДИВЭ на фермент сначала повышает его и активность до определенных пределов, а затем разрушает активный центр фермента, вследствие чего активность падает.

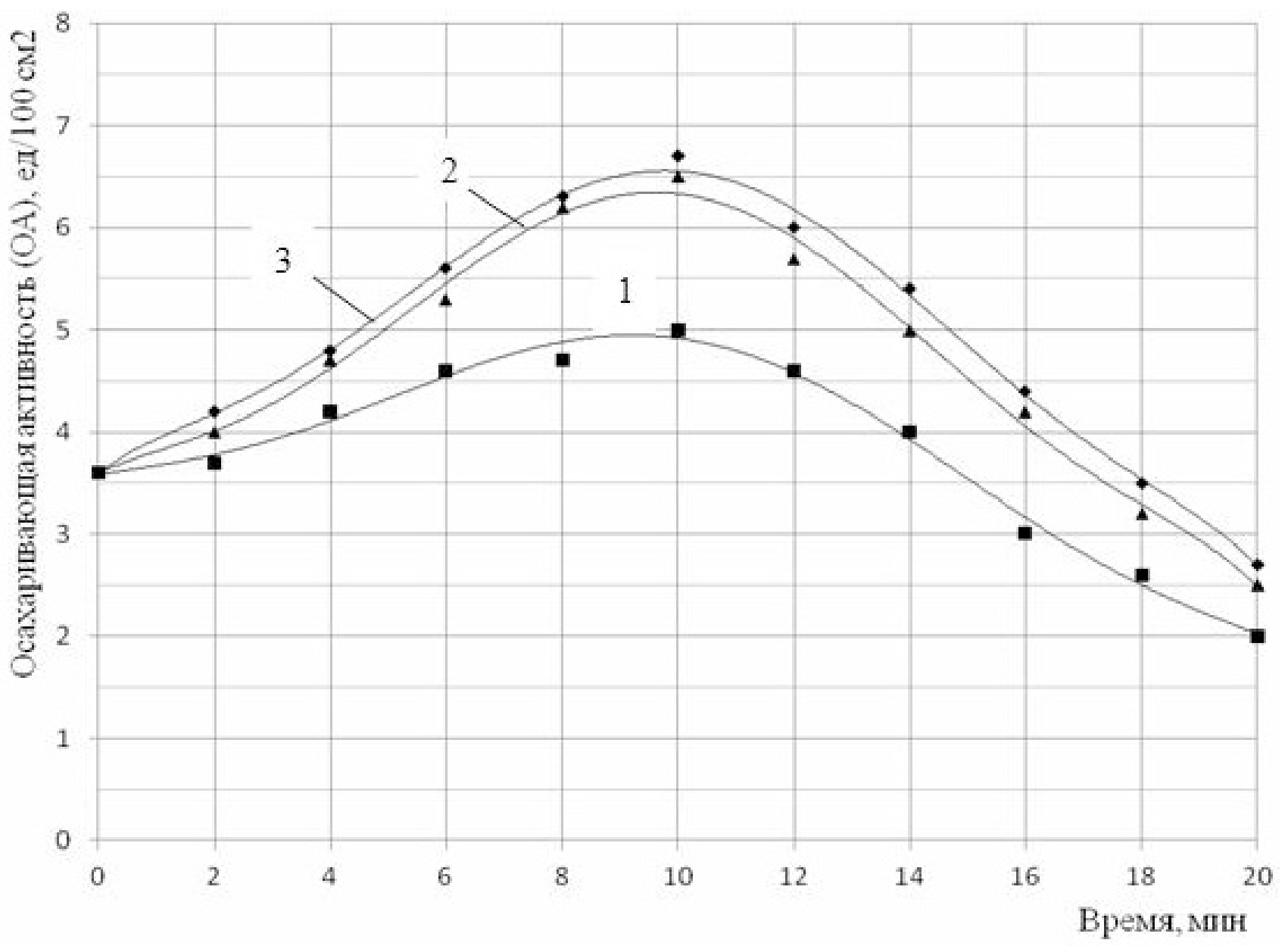

Рис. 4. Зависимость осахаривающей активности от продолжнтельности процесса гидролиза, при частоте пульсаций: 1 - 1 кГц; $2-3$ кГц; $3-5$ кГц. 
Табл. 3. Зависимость осахаривающей активности ферментов от скорости сдвига потока и продолжительности гидролиза

\begin{tabular}{|c|c|c|c|c|c|c|c|c|c|}
\hline \multirow{2}{*}{ Скорость сдвига потока, $10^{3} \mathrm{c}^{-1}$} & \multicolumn{10}{|c|}{ Время, мин } \\
\cline { 2 - 10 } & 0 & 3 & 5 & 7 & 10 & 12 & 15 & 17 & 20 \\
\hline \multirow{2}{*}{30} & 3,4 & 3,5 & 4,2 & 4,8 & 5,5 & 6,0 & 5,3 & 4,5 & 3,4 \\
50 & 3,4 & 3,7 & 4,5 & 5,3 & 6,1 & 6,0 & 5,2 & 4,0 & 2,1 \\
70 & 3,4 & 3,9 & 4,8 & 6,0 & 6,0 & 5,1 & 3,5 & 2,1 & 0,5 \\
\hline
\end{tabular}

\section{Выводы}

Приведенные исследования убедительно доказывают, что применение метода ДИВЭ при переработке зернового крахмалосодержащего сырья позволяет интенсифицировать процесс и снизить энергозатраты. В работе показана возможность проведения четырёх технологических этапов переработки зерна (диспергирование, перемешивание, растворение, нагревание, гидролиз) в одном РПА. Изучено действие ДИВЭ и конструктивных особенностей РПА на процесс гидролиза крахмала.

\section{ЛИТЕРАТУРА}

1. Басок Б.И. Дискретно-импульсный ввод энергии в технологии бродильного производства/ Б.И. Басок, Ободович А.Н., Пироженко И.А., Коба А.Р. // Пром. теплотехника. - 2003. - Т. 25, № 4 (приложение №1). - С. 94 - 99.
2. Ободович А.Н. Совершенствование технологии приготовления сусла из крахмалосодержащего сырья в спиртовом производстве с применением метода дискретно-импульсного ввода энергии/ А.Н. Ободович, Т.Л. Грабова, А.Р. Коба // Пром. теплотехника. - 2009. - Т. 31, № 6. - C. $81-87$.

3. Ободович А.Н. ДИВЭ - интенсифицирующий метод гидролиза высокомолекулярных соединений / А.Н. Ободович, А.Ю. Лымарь // Промышленная теплотехника. - 2013. - Т. 35, № 6. - C. $23-30$.

4. Мальиев П.М. Технология бродильных производств / П.М. Мальцев - 2-е изд., перераб. и доп. - М.: Пищевая промышленность, 1980. -569 с.

5. Долинский А.А. Метод дискретно-импульсного ввода энергии и его реализация: монография / А.А Долинский, А.Н. Ободович, Ю.А. Борхаленко. - Х.: Віровець А.П. “Апостроф”. - 2012. $-185 \mathrm{c}$. 


\section{REDUCTION OF ENRGY CONSUMPTION \\ IN THE PROCESSING OF STARCH MEDIA BY METHOD OF DISCRET - PULSED ENERGY INPUT}

\section{Obodovich A.N., Lymar A.J., Kostyk S.I., Sidorenko V.V.}

Institute of Engineering Thermophysics

of National Academy of Sciences of Ukraine, 2a, Zhelyabova str., Kyiv, 03680, Ukraine

The article presents the results of applying the method of discrete-pulsed energy input (DIVE) in the processing of starch media. Examine the extent that they affect the DIVE on the degree of hydrolysis of starch saccharifying activity of enzyme preparations. The paper shows the possibility of four process stages of grain processing (dispersion, mixing, dissolving, heating, hydrolysis) in one apparatus. These data clearly show that the application of the method in the processing DIVE grain starch raw materials allows to intensify the process and reduce energy costs. References 5, tabl. 3, fig. 4.

Key words: discrete-pulse energy input, hydrolysis, wort.
1. Basok B.I. Discrete-pulse energy input into the production of fermentation technology/ Basok B.I., Obodovich A.N., Pirogenko I.A., Koba I.A.// Promyshlennaya teploteknika. - 2003. - V. 25, № 4 (enclosure №1). - P. 94 - 99 (Rus.)

2. Obodovich A.N. Improving the technology of preparation of the wort from starch raw material in alcohol production using the method of discretepulsed energy input / Obodovich A.N., Grabova T.L., Koba I.A. // Prom. teploteknika - 2009. - V. 31, № $6 .-$ P. 81 - 87 (Rus.)

3. Obodovich A.N. DIVE - intensifying method of hydrolysis of high-molecular compounds / Obodovich A.N. Lymar A.J. // Prom. teploteknika. 2013. - V. 35, № 6 - P. 23 - 30 (Rus.)

4. Malsev P.M. Fermentation Technology / Malsev P.M. - Second edition revised and supplemented. - Moscow: Food industry, 1980. - 569 (Rus.)

5. Dolinskiy A.A. The method of discrete-pulsed energy input and its implementation: Monograph/ Dolinskiy A.A., Obodovich A.N., Borkhalenko J.A. - Kharkov: Vyrovanets A.P. “Aposrof”/ - 2012. 185 p (Rus.)

Получено 08.10.2014 Received 08.10.2014 